\title{
MISCELLANEOUS.
}

\section{Note on Dr. Hinde's Tertiary Sponge-spicules.}

By R. v. Lendenfeld.

Dr. Hinde ("On the Sponge-remains in the Lower Tertiary Strata near Oamaru, Otago, New Zealand," Journ. Linn. Soc., Zool. vol. xxiv.) has described and figured a number of sponge-spicules from the Oamaru beds.

In studying Hinde's figures of tetraxon and polyaxon spicules I have come across several forms exceedingly similar to spicules observed by me in recent sponges different from those mentioned by Hinde as their nearest recent allies. These are the following:-

Protricen (pl. xiii. figs. 16, 17, p. 234), referred by Hinde to Craniella cranium, is identical with the protriæn of Stelletta hispida (Buccich).

Dichotricen with short rhabdom (pl. xiii. figs. $7,8,11,12$, p. 234), referred by Hinde partly to Stelletta and Geodites, is in every way similar to the dichotriæn of Erylus discophorus (O. Schmidt).

Dichotricen with long rhabdom (pl. xiii. figs. $3,4,5$, p. 233), referred by Hinde to Geodites, is similar to the dichotriæn of Ancorina cerebrum (O. Schmidt).

Anatricen (pl. xiii. figs. 19-24, p. 235) is identical with the anatriæn of Geodia cydonium (R. v. L. in sched.) [i. e. Geodia gigas, O. Schmidt; Cydonium Mülleri, Fleming; Georlia zetlandica, Johnston, \&c.].

Aster (pl. xiv. fig. 18, p. 239), compared by Hinde to that of Geodia tuberculosa (Bowerb.), is doubtless a spicule from the ectochrote of a species of Stelletta.

Aster (pl. xiv. figs. 28, 29,30, p. 237), compared by Hinde to that of Stelletia intermedia (O. Schmilt), is identical with an aster occurring in the lower portion of the cortex of the Geodia cydonium (R. v. L.) above mentioned.

\section{A Contribution to the Knowledge of the Male Sexual Organs of the}

Diptera. Вy N. Сноцоркоvsкy, St. Petersburg.

Our knowledge of the anatomy of the male sexual organs of the Diptera is tolerably scanty. While the coarser structure of the parts in question has been studied by L. Dufour and Loew, and we have isolated notes thereon by other investigators also *, their finer constitution has hitherto been entirely neglected. In order to supply

* L. Dufour, "Anatomie générale des Diptères," Ann. Sc. Nat. 3 sér. t. i., 1844 ; L. Dufour, " Recherches anatom. et physiol. sur les Diptères," Mém. presentés à l'Acad. Sei. Paris, t. xi., 1851 ; H. Loew, 'Horae anatomicae.-Entomotomien,' Heft i.-iii., Posen, 1841 ; H. Loew, "Beitr. zur Kennt. d. inneren Geschlechtstheile d. zweifl. Insecten,' Germar's 'Zeitschrift f. Entomologie,' iii., 1841 ; Suckow, "Die ieschlechtsorg. d. Insecten," Hens. Zeitschr. f. organ. Physik, 2 Bd., 1828; Meigen, 'Systemat. Beschr. der bekannten eurup. zweifl. Insecten, 1818-38, tab. 34, 35, 43 ; Hegetschweiler, 'De insectorum genitalibus,' Turici, 1820 ; Swammerdam, 'Bibel der Natur,' 1752, tab. 42, 43 ; Burmeister, 'Handbuch d. Entomologie,' 1832, i. Bd., pp. 215-236. 
this deficiency I investigated last summer by means of sections the male sexual organs of certain Diptera, especially the genus Laphria.

As we are already aware, the internal male genital apparatus of Laphria (as of the Asilidæ in general) consists of two long spirally coiled testicular tubes, two vasa deferentia, two long tubular accessory glands, and a short ductus ejaculatorius. The testes are loosely surrounded by a common envelope, which is of a dark red colour and is well supplied with tracheæ. Beneath the envelope lies a fine layer of fat-granules. In structure this layer corresponds to the membrane with which each follicle of the testis of the butterfly is separately clothed, and, like it, it is in all probability formed by the concrescence of the hypodermal layer of the tracheæ* ${ }^{*}$.

The wall of the testicular tube consists of a thin but firm nucleated membrane, beneath which there further lies a structureless membrana propria. Parietal epithelium is not found in the testis, except at the spot where it passes into the vas deferens, where the epithelium appears at first flattish, and then continually more and more columnar. The vasa deferentia as well as the accessory glands possess an external membrane similar to that of the testis, while the ductus ejaculatorius is surrounded by a thick multilaminar membrane, which is very feebly stainable with carmine and contains numerous nuclei. This membrane ilso envelopes the vasa deferentia and the accessory glands at their transition into the ductus ejaculatorius, in consequence of which the four tubes when examined under a low power appear to be united for a space into a common cord. The epithelium of the vasa deferentia is cylindrical, but not columnar; in the accessory glands the cells of the epithelium are very columnar in places, and form a number of longitudinal ridges, projecting considerably into the lumen of the gland, between which the epithelium is flat. The ductus ejaculatorius is clothed with columnar cylindrical epithelium, the cells of which contain large vacuoles in their peripheral extremities, and secrete a thick chitinous intima.

The tracheæ, which surround the testis in abundance, do not penetrate into its cavity, just as is also the case in other insects. In this respect $I$ most decisively maintain my statements as to the structure of the testis of the butterfiy, in opposition to the objections of Tichomirow and Koschewnikoff $\uparrow$. In his paper on the sexual apparatus of the humble-bee ("Drohne") Herr Koschewnikoff indeed confirms my view, by alluding to the fact that in Apis the tracheæ do not penetrate into the cavities of the separate testicular tubules. Further on, however, he writes:- "If we consider the structure of the envelopes, the entire testis of the humble-bee is

* N. Cholodkovsky, 'Der männliche Geschlechtsapparat der Lepidcpteren,' St. Petersburg, 1886 (in Russian).

† Tichomirow, 'Entwicklung'sgeschichte von Bombyx mori,' Moskau, 1882 (in Russian) ; Koschewnikoff, 'Ueber den Bau des Geschlechtsapparates der Drohne,' Moskau, 1891 (in Russian) ; Koschewnikoff, " Zur Anatomie der männlichen Geschlechtsorgane der Honigbiene," Zool. Anzeiger, 1891, no. 376, pp. 393-39' (Ann. \& Mag. Nat. Hist. ser. 6, vol. ix., Feb. 1892, pp. 185-187). 
comparable rather to a section (' scompartemento', Verson ; 'Samenfollikel,' Cholodkovsky) of the compound testis of the Lepidoptera." But since the cavity of the genital glands is undoubtedly homologous in different insects, the distinction proposed by Koschewnikoff has no justification whatever. In the form in which he would refute my view in his paper in the 'Zoologischer Anzeiger' (no. 376; Ann. \& Mag. Nat. Hist., Feb. 1892 :- "The belief that in butterflies there are no tracheæ within the testis is erroneous"), Koschewnikoff's reply is even devoid of all actual foundation, for I never said that there are no tracheæ within the testis: I merely maintained, as I do still, that into the cavity of the testis, where balls and bundles of spermatozoa lie, the tracheæ do not penetrate.

The spermatogeny of Laphria is of a very peculiar kind, which vividly reminds us of the process described by Verson for Bombyx mori* ${ }^{*}$. In the blind club-like swollen end of the testicular tube lies a colossal cell, visible with the naked eye; this is the spermatogonia, from which the entire contents of the testis are derived. In Bomby $x$ this spermatogonia is found in the larval stage, but in Laphria it remains active in the imago and exists simultaneously with numerous completely dereloped bundles of spermatozoa, which distend the middle and lower sections of the testicular tube. From this cell proceed ray-like outgrowths of plasma (as in the case of Bombyx mori), in which numerous nuclei are imbedded. I have never found a single large nucleus (Verson) in the central mass of the plasma of the spermatogonia, but always several large nuclei of irregular and very varied form, which took either a slight or a very deep stain from carmine. In addition to this I always found in the central plasma-mass of the spermatogonia numerous small chromatin corpuscles, which sometimes appeared somewhat curved and were frequently united into little heaps. Judging by these figures the division of the nucleus in the spermatogonia of Laphria is not amitotic (as described by Verson for Bombyx mori), but is effected by typical mitosis.

As regards the other groups of Diptera, my knowledge of the finer structure of the sexual apparatus is at present still incomplete. I therefore here venture to say only a few words as to the testes of the genus Calliphora. In these flies the two testes are each enclosed in an orange-yellow capsule, and in addition to this are surrounded by a special saccule of the fat-body. Within this sacrule, that is between its wall and the testicular capsule, lie peculiar cells of very large size, whose plasma contains numerous large globules, which are apparently hard and take a very deep stain from fuchsine. The significance of these remarkable cells appears at present quite enigmatical.-Zoologischer Anzeiger, xv. Jahrg., no. 391, Мay 16, 1892, pp. 178-180.

* E. Verson, 'La spermatogenesi nel Bombyx mori', Padova, 1889 ; Verson, "Zur Spermatogenesis," Zool. Anzeiger, 1889. 


\section{$2 \mathrm{BHL}$ Biodiversity Heritage Library}

Kholodkovskiĭ, N. A. 1892. "A contribution to the knowledge of the male sexual organs of the Diptera." The Annals and magazine of natural history; zoology, botany, and geology 10, 268-270.

https://doi.org/10.1080/00222939208677406.

View This Item Online: $\underline{\text { https://www.biodiversitylibrary.org/item/88260 }}$

DOI: https://doi.org/10.1080/00222939208677406

Permalink: $\underline{\text { https://www.biodiversitylibrary.org/partpdf/65023 }}$

\section{Holding Institution}

Smithsonian Libraries

\section{Sponsored by}

Smithsonian

\section{Copyright \& Reuse}

Copyright Status: Public domain. The BHL considers that this work is no longer under copyright protection.

This document was created from content at the Biodiversity Heritage Library, the world's largest open access digital library for biodiversity literature and archives. Visit BHL at https://www.biodiversitylibrary.org. 